\title{
Geotechnical Engineering Aspect Related to Pidie Jaya-Aceh Earthquake Disaster and Mitigation
}

\author{
Munirwansyah $^{\#}$, Reza Pahlevi Munirwan ${ }^{\#}$, Halida Yunita ${ }^{\#}$ \\ ${ }^{\#}$ Civil Engineering Department, Faculty of Engineering Syiah Kuala University \\ E-mail: nir_geotechnical@unsyiah.ac.id
}

\begin{abstract}
Earthquake catastrophe in Pidie Jaya has caused damages to the city of Meureudu, Aceh-Sumatra Indonesia. Based on preliminary study for buildings and infrastructures, the geotechnical engineering aspects damages-related are presented. Seismic motion effect damage of earthquakes such as liquefaction of soil, lateral spreads, and ground failure were the majority effect for infrastructures and buildings. Moreover, failures of almost of multi-storey buildings and mosques along the national road lines are because the effect of peak surface accelerations and earthquake wave propagation forces which are very close with epicenter coordinates $5.308 \mathrm{~N} / 96.269^{\circ} \mathrm{E}$ in $4 \mathrm{~km}$ radius. Seismic back investigates of the Aceh's fault seismic source as well as initial probabilistic seismic hazard analysis post-Pidie Jaya earthquake for city of Mereudu is offered. Liquefaction potential analysis from the estimation of peak ground acceleration was conducted. Geotechnical aspect and substructure failure characteristics to infrastructure and housing damages due earthquake are also reported. The earthquake has caused 104 people deaths, 2.474 unit houses in total need to be rehabilitated and rebuilt, almost $10 \mathrm{~km}$ of roads and 50 bridges need to be reconstructed. Some descriptive countermeasures for reconstructions of geotechnical engineering aspects and mitigation are also provided.
\end{abstract}

Keywords — geotechnic aspect; earthquake; disaster; mitigation.

\section{INTRODUCTION}

Pidie Jaya-Aceh Sumatra earthquake has happened on December 7th, 2016. The magnitude of the earthquake was $(\mathrm{M}=6.4)$ at hypocenter depth of $10 \mathrm{~km}$ beneath the epicenter as shown in Fig. 1. The epicenter of the earthquake is $5.308^{\circ} \mathrm{N} / 96.269^{\circ} \mathrm{E}$ at the railroad, about $4 \mathrm{~km}$ west of Mereudu city and $150 \mathrm{~km}$ east of Banda Aceh city, the earthquake was of type lateral strike-slip fault mechanism, the earthquake magnitude, and epicenter as shown in Fig. 2.

The terrible earthquake in Aceh is followed by an enormous impact on the site first day (48 times), second day (17 time) and third days etc, (7time/day). Many areas have been a strike during the earthquakes in Pidie Jaya district and felt powerfully in Manohara, Meurudu, Samalanga and Bireuen district of Aceh province.

\section{A. Destruction Assessments}

The Pidie Jaya earthquake has triggered remarkable sufferers and disastrous along suffered zone, mainly for several cities namely Meurudu, Samalanga, Bireuen, and Sigli. Most of the structures along the coastlines and central cities were the loss of function after the 6.4 SR magnitude of an earthquake.

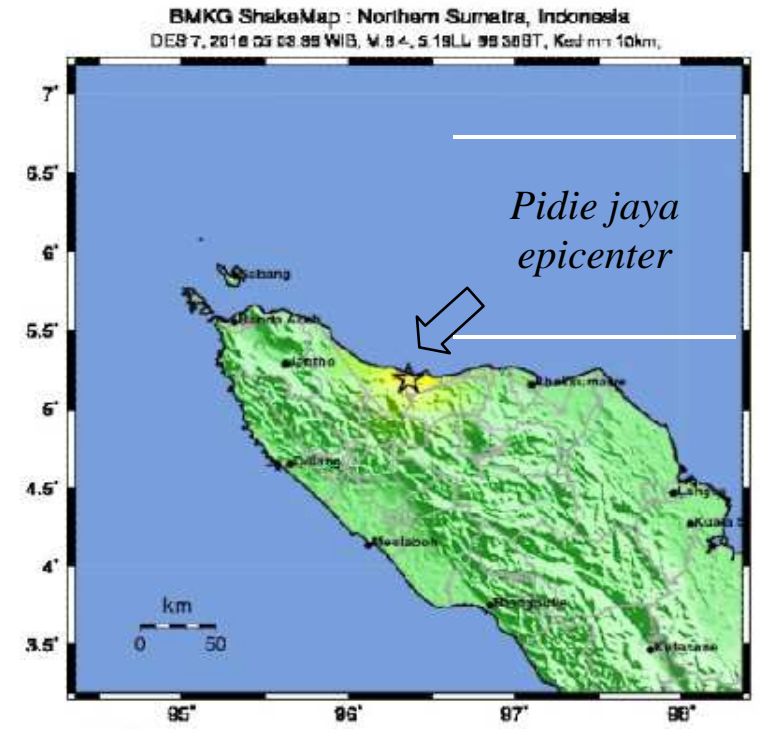

Fig.1 Pidie Jaya fault and epicenter 7th December 2016 (USGS, 2016)

Fig. Three shown maps of the epicenter distribution of Aceh-Sumatra, Indonesia about M > 5.0 since 1990 - 2016, as shown in Fig. 4 the Meurudu City in Pidie Jaya district is also located around $200-300 \mathrm{~km}$ from subduction line along the west coast of Indian Ocean. Furthermore, future 
earthquake influence in Pidie Jaya is necessary to be implemented for future development with mitigation and disaster prevention principal for rehabilitation of government infrastructure and public facilities in Pidie Jaya which caused by 7th December 2016 earthquake as suggested in [1] which mention that every big city in Indonesia should develop micro-zonation map.

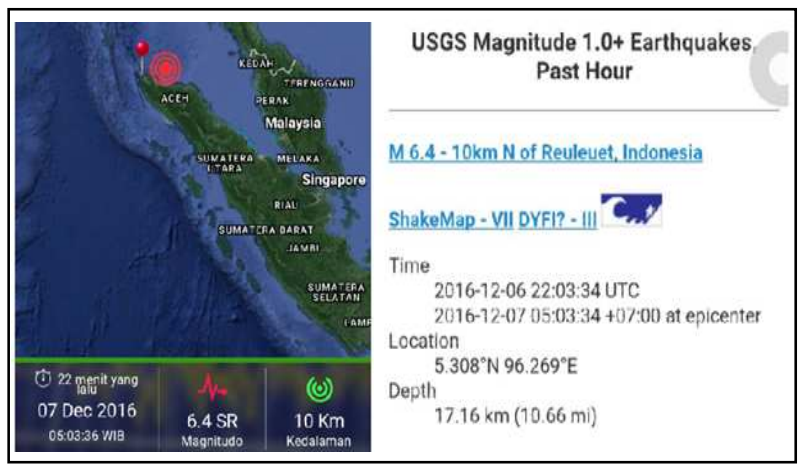

Fig.2 Pidie Jaya Earthquake M.6.4, 26 December 2004 Aceh Province, Sumatra - Indonesia (USGS, 2016).

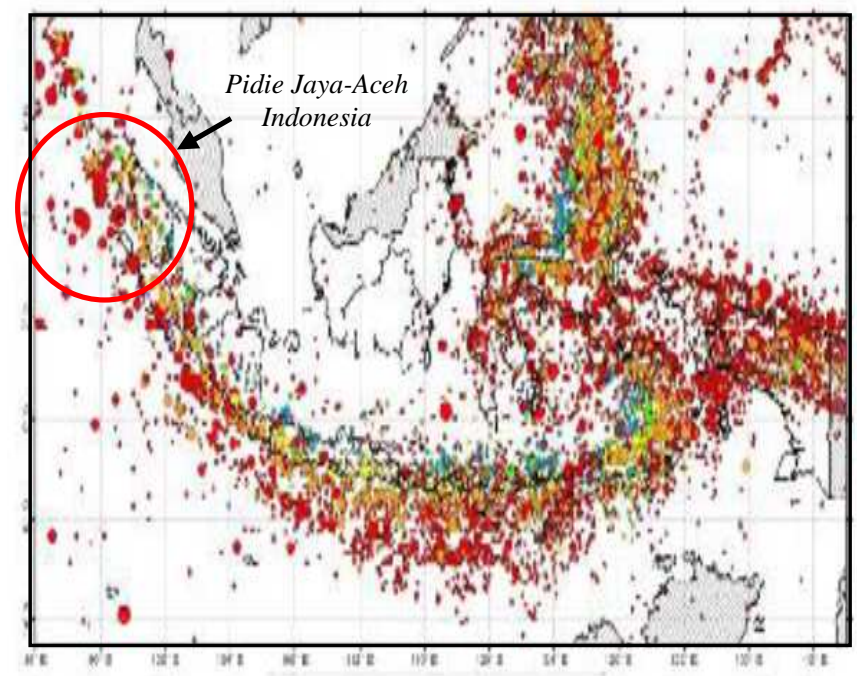

Fig. 3 Pidie Jaya and Epicenter map distribution of the Aceh-Sumatra and Indonesia, $\mathrm{M}>5$. (1900-2016).

\section{B. Building Damages}

Many infrastructures damages during Pidie Jaya earthquake have been recognized based on site survey. Pidie Jaya earthquakes had devastated many weak structures because of quite high ground motion. Moreover, seismic loads act as a lateral load for the structures. There were some differences in building and infrastructures failure and damages types observed. Slightly non-structural to collapsed damages were observed. Several three-storey structures were completely collapsed, whereas some other structures only experience slight non-structural damages.

The earthquake has caused approximately 104 people deaths and missing. Some of the building failures were stated. Mostly for schools, government facilities, hospitals, and housings which have been broken. More than 2,474 unit houses in total need to be rehabilitated and rebuilt. Almost
$10 \mathrm{~km}$ of roads and 50 bridges need to be rebuilt. The casualties in Meurudu cities have caused disastrous damages.

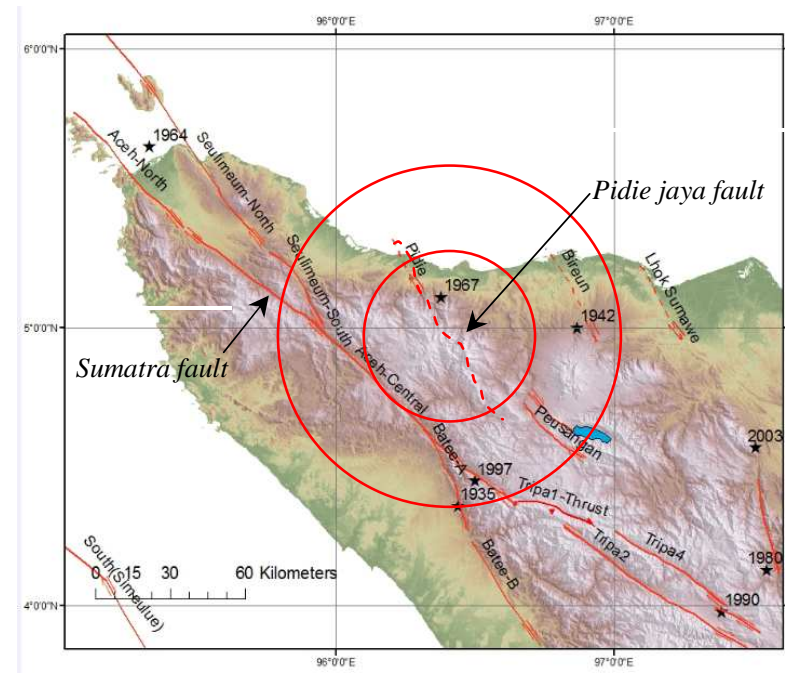

Fig.4 Pidie Jaya fault, another local fault, and great Sumatra Fault

Fig. 5 shown three extreme collapsed; (a) buildings, (b) Mosques and (c) High peak base acceleration bridge abutment with possibly of low seismic amplification. Aceh province west shore is categorized in zone 5 to 6 scale (including the high score) for peak base acceleration (PBA) from $0.3 \mathrm{~g}$ to $0.4 \mathrm{~g}$ and nearby $0.25 \mathrm{~g}$ to $0.3 \mathrm{~g}$ for Banda Aceh region [2].

\section{Earthquake History in Aceh Province}

The objective of the study is an earthquake in Aceh as one of the most significant earthquakes which already happened in "mega-trust' of zone seismic subduction in Indo-Australia and Euro-Asian crust. To assess peak base acceleration (PBA) at damage cities of Aceh province, initial wave simplification of the earthquake which has been conducted. The implementation of appropriate simplification analysis is needed, because of lack attenuation relationship available from earthquake record in this region. Consequently, attenuation functions which symbolize comparable mechanism are used in Aceh earthquake.

\section{MATERIAL AND METHOD}

\section{A. Simplification of the Pidie Jaya-Aceh Sumatra 2016 Earthquake}

The implementation of appropriate simplification analysis is needed, because of lack attenuation relationship available from earthquake record in this region. Consequently, attenuation functions which symbolize comparable mechanism are used in Aceh earthquake.

Indonesian-Society has directed an investigation survey for earthquake and disaster for Geotechnical-Engineering (ISGE) as the fellow of International-Society for SoilMechanics and Geotechnical-Engineering (ISSMGE) task force, just aftershock happening with first author coordination to investigate the failure zones and failures scale on structures and residential houses of Pidie Jaya Mereudu city. During the survey, it shows that among buildings in the fault zone located around $2-5 \mathrm{~km}$ away from closes epicenter, two stories, four-storey or taller 
buildings with some open space with strong foundation survive after the earthquake. However, most three-storey reinforced concrete buildings about 2-3 $\mathrm{km}$ from the epicentre at Samalanga and Mereudu city wholly destroyed and collapsed. The concept of performance-based seismic design is suggested to apply in earthquake risk area.

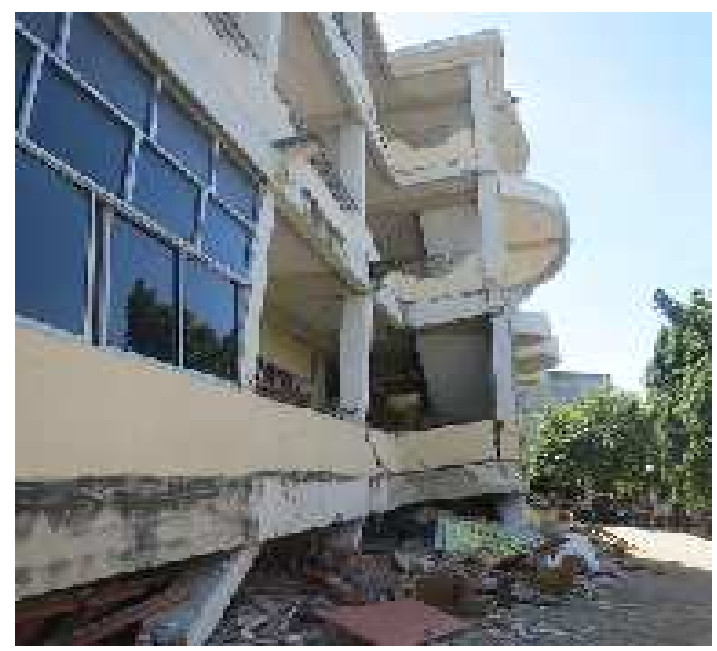

(a)

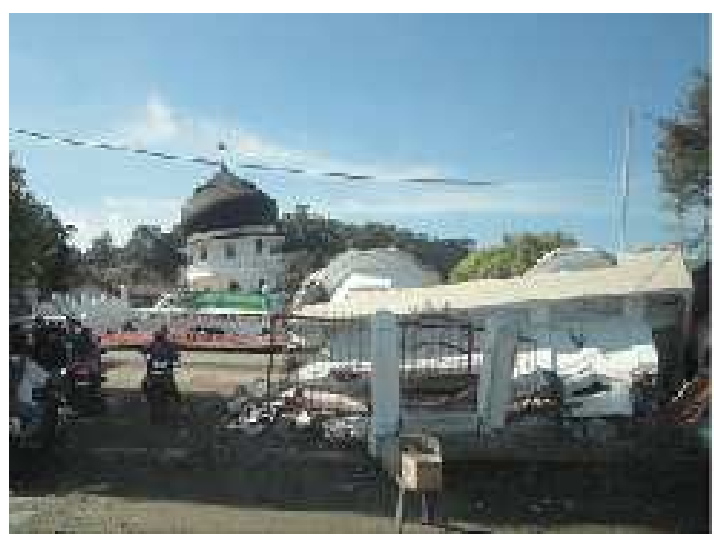

(b)

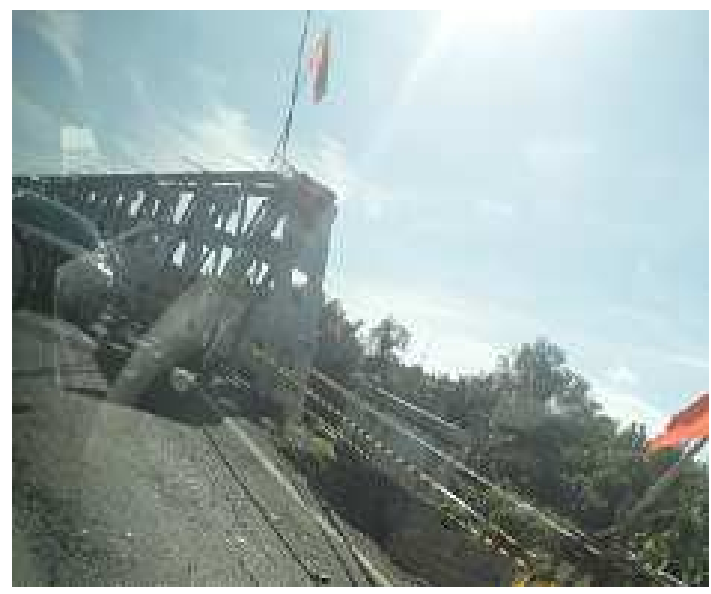

(c)

Fig. 5 (a) Total building collapse, (b) Mosque collapse and (c) Bridge abutment failure.

\section{B. Geotechnical Failures due to Earthquake}

A lot of possible factors related to variation in damages level. One of the factors would be site condition effect of bedrock to ground surface seismic amplification. Fig. 6 displays ground failure of road located along fishpond with the soft ground condition. Research about soil condition and some stabilization method in Aceh [3] and [4] are necessary to conduct to understand deeper the site condition of Aceh soil histories.

The damages level variation is varied such as exposure of the buildings and the foundations, peak ground acceleration variation of seeming by different local soil profile, and structures which might involve soil settlement or resonance induced foundation failures. Besides huge seismic loads, excessive of groundwater and inadequate strength of soil should also be considered [5]. Furthermore, local geological and geotechnical histories should also be a part of further measurements [6].

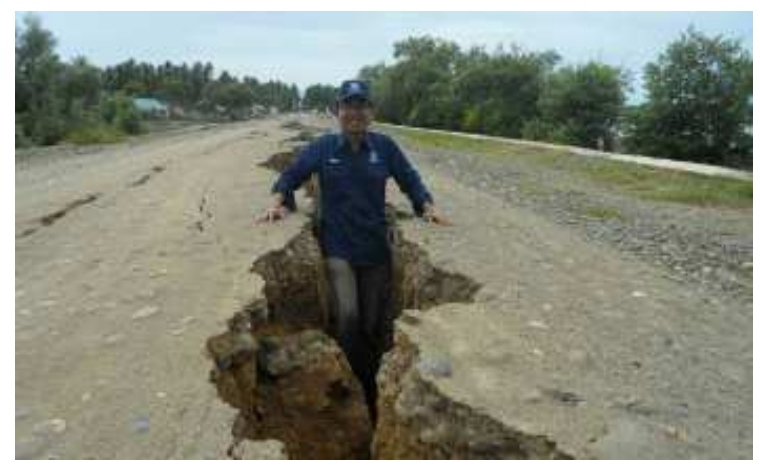

(a)

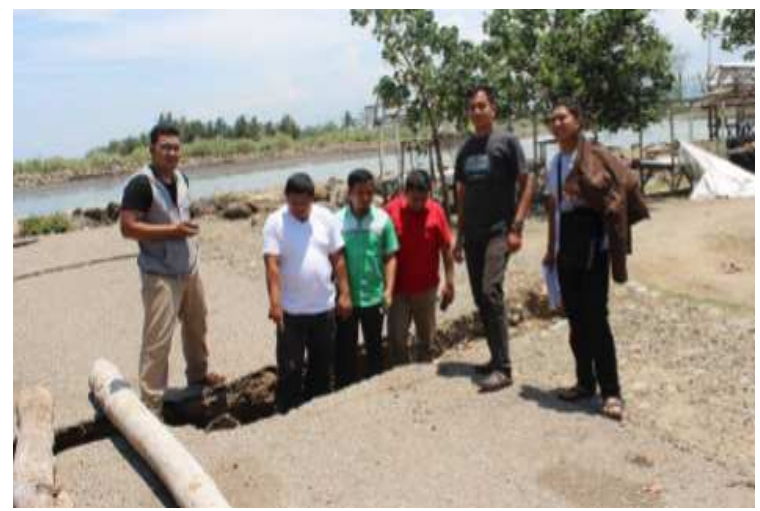

(b)

Fig. 6 (a) Ground failure of the road (b) located on Manohara fishpond with soft soil ground condition

From Fig. Seven it is shown that the settlement of a structure is because of building overturning through ground shaking during the earthquake. The government office of the council for prosecution and Government office of Pidie Jaya district building failures seems because of lack of structural integrity rather than foundation failure and overburden pressure phenomena.

In overall, infrastructure damages like bridge embankments and roads also vary. The locations and variation possibility of seismic amplification for different local ground conditions seem to have influences for the damages. Moreover, liquefaction induced seen on the coast 
and some of the infrastructures failures were also noticed as foundation failures.

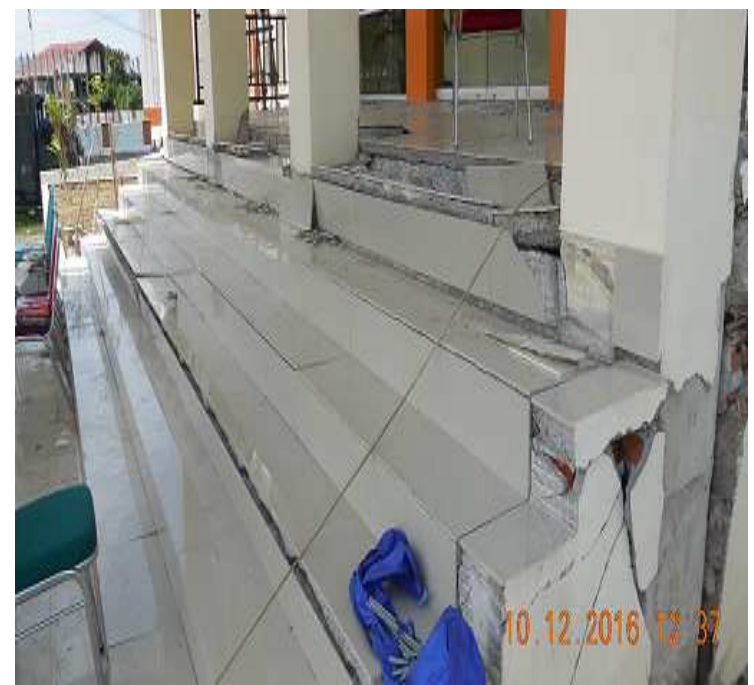

(a)

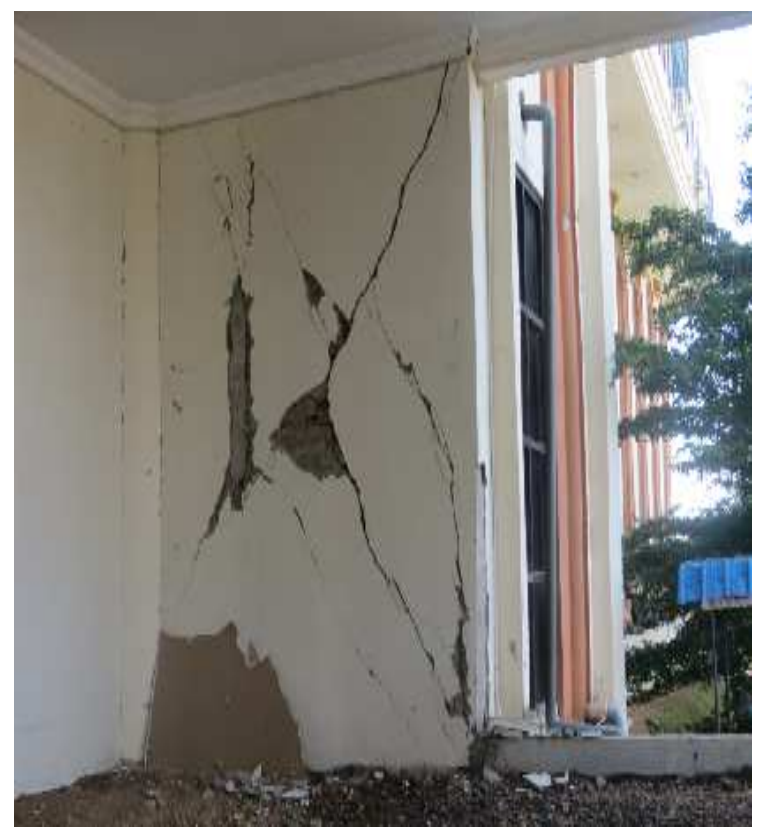

(b)

Fig. 7 Settlement caused by building rocking during earthquake ground shaking. (a) Office of the counsel for the prosecution and (b) Government office of Pidie Jaya district.

\section{Liquefaction Reconnaissance}

Based on investigations, specific existences of potential liquefaction also ground failure in the area along the shoreline were detected as shown in Fig. 8 and Fig.9. Considering that common conditions of geotechnical data are medium dense with silty sand layers dominate in the soil profile, it seems that liquefaction occurred within the area just after firm earthquake shake with low to medium dense loose silty sand.

As only limited geotechnical data available, the presence of sandy like soil in a pond area inshore track is estimated. Fig. 8 displays completely collapse of mosques due to ground cyclic movement and resonance between natural soil frequency and structures frequency during an earthquake. Embankments and foundation failures of bridges and buildings also were predicted due to resonance failures.

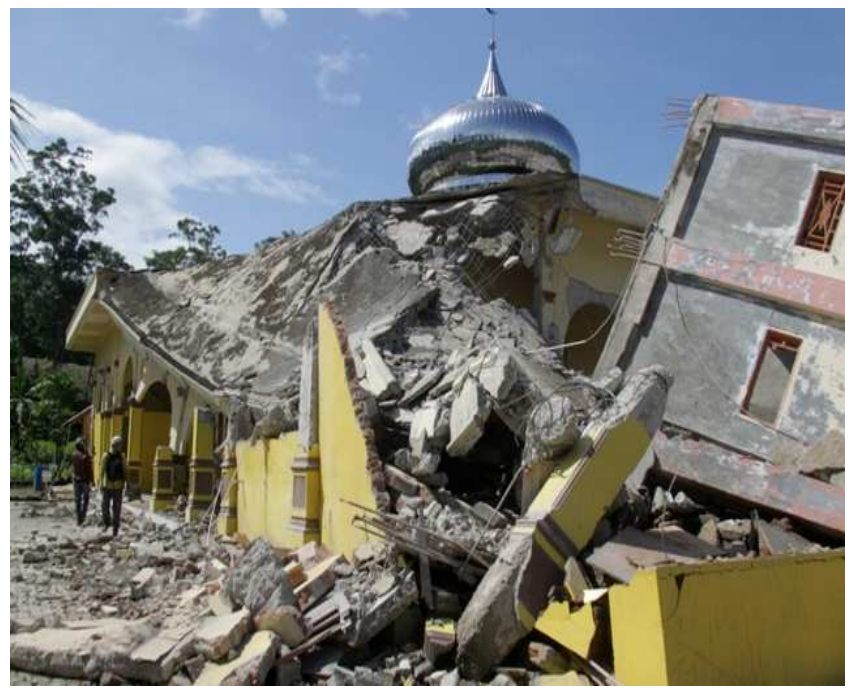

Fig. 8 Failures of vulnerable mosque due to high amplification of seismic ground motion inducing foundation failure.

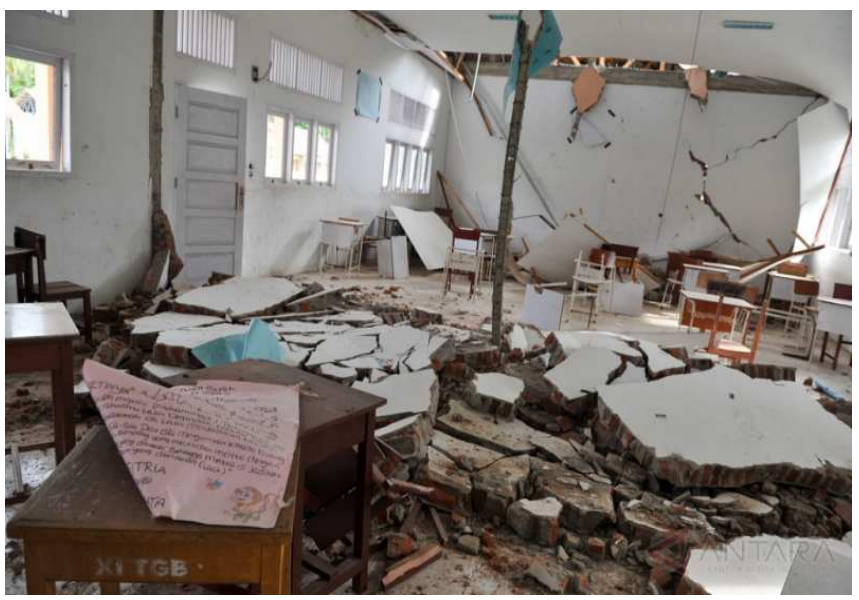

Fig. 9 Failures of school due to high amplification of seismic ground motion inducing foundation failure.

Failures of embankments and bridges seem to be caused by due to poor design. Some several issues associated with variation in damages level. One of it is the effect of soil profile at the seismic local ground condition which increases from bedrock to ground surface beneath structures. The difference in the level of damages is measured vary by buildings vulnerability and the foundations, difference in peak surface acceleration of probable different site condition which might have liquefaction and ground failure, as shown in Fig. 10 and Fig. 11 respectively.

\section{RESULT AND DISCUSSION}

\section{A. Probabilistic Seismic Hazard Analysis}

Research of seismic hazard criterion of return period for 200 years was used in Indonesian seismic code prior 2002 as in [1]. Existing Indonesian seismic hazard for the return period of 500 years as agreed in many international seismic 
codes (10\% possibility of not being surpassed in 50 years) [1] and [2].

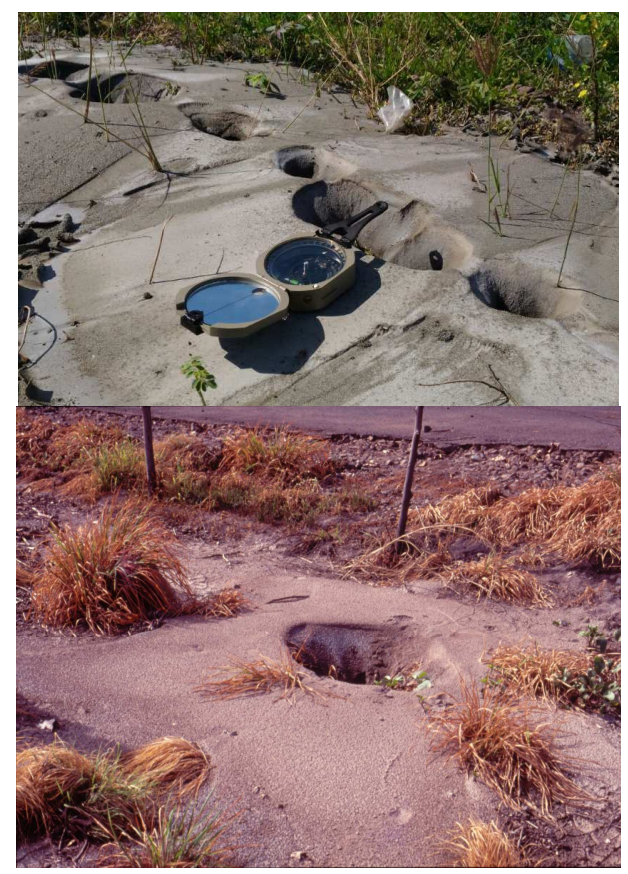

Fig. 10 Liquefaction phenomena at Manohara shorelines Pidie Jaya Aceh earthquake 7th December 2016.

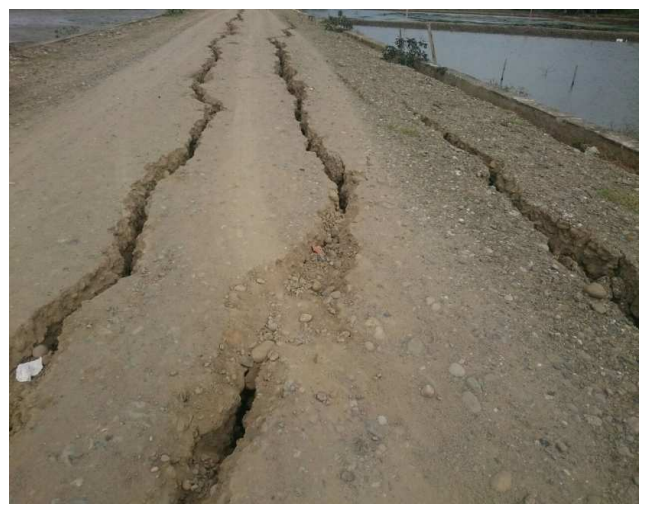

Fig. 11. Ground failure in Manohara-shorelines Pidie Jaya Aceh earthquake 7th December 2016.

The possibility effort is established from a simple concept which earthquake resilient design of infrastructures show safety in general to prevent human life loss, personal injury and to reduce residential destruction and confirming for vital services are preserved during and after the earthquake [7]. Based on the existing codes, 0.25-0.30g was used for Aceh PBA. Seismic potential post - Pidie Jaya Aceh earthquake might need to be re-assessed as an input for a current seismic load as in Pidie Jaya earthquake data. Sumatra Fault existence which passes to the city rises the apprehension of the future earthquakes originally from Sumatera Fault rather than from the subduction sources.

\section{B. Seismic Risk and Microzonation Map}

Preliminary probabilistic seismic hazard analysis (PSHA) method [7] was used for Mereudu post-Pidie Jaya-Aceh earthquake which will be shown in future research as [1], [2], and [8]. The function of differentiating attenuation for subduction, 3-dimensional seismic source zones and strikeslips source zones have been considered. Attenuation function was implemented for subduction zones [8], and for the lateral strike-slips seismic sources [9]. Initial PSHA results specified that PBA is near $0.25 \mathrm{~g}$, more caution needs to be done through on possible of this close to source fault for generating future large earthquakes and as a consideration code for Aceh seismic building.

Seismic source zones used in preliminary PSHA is shown in Fig. 12 and Fig. 13. The map of seismic microzonation would be valuable as a control for the supervision or private sector that dynamic load which has been signified. Furthermore, the map would be important for improvement of city maps risk within the city, which also needed spatial planning. Moreover, the combination of microzonation map with vulnerability in seismic risk assessment is used to formulate risk mitigation strategies for city development.

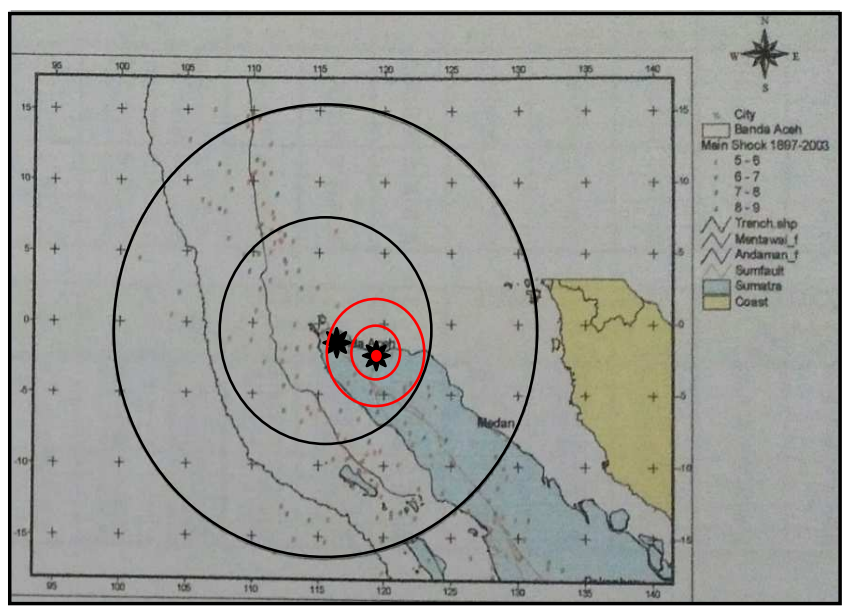

Fig. 12 Seismicity and source zone (epicenter) within a radius of $300 \mathrm{~km}$ from Andaman earthquake $(M=9.1,2004)$ and radius $4 \mathrm{~km}$ from Pidie Jaya earthquake $(M=6.4,2016)$.

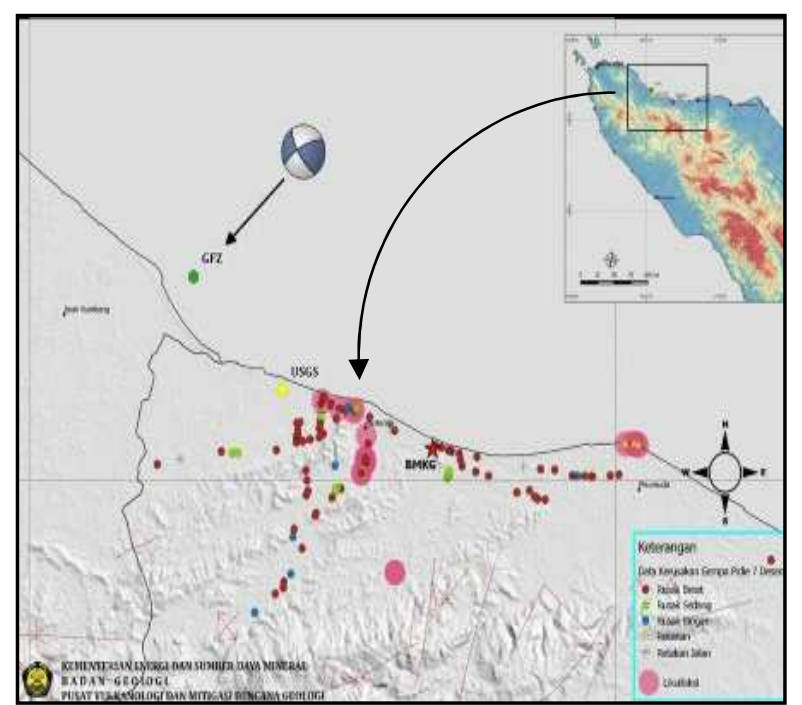

Fig.13. Seismicity summary of Pidie Jaya-Aceh aftershock earthquake 7th December $2016(\mathrm{M}=6.4)$.

Geotechnical earthquake engineering research related like site response analysis have to be focused for emerging characteristic of dynamic parameters like shear modulus 
(Gmax), shear wave velocity (Vs), and damping (D) to buildings and infrastructures design after the massive earthquake [10], and [11]. Understanding ground failures characteristics of possible upcoming earthquake need to be considered. For capturing an earthquake ground motion characteristic, the installation of strong-motion records is used. Site conditions effect signified by dynamic properties have to be measured because dynamic load to the buildings suitably characterized. Seismic design ranges signifying, local site condition result and seismic characteristic crushed motions from subduction and near the fault, seismic sources need to be signified for seismic building codes development for Pidie Jaya.

Microzonation seismic map established from geotechnical subsurface figures collection which would identity site with vary seismic response. Microzonation study for Pidie JayaAceh needs to be established using available approaches like site condition map and or response spectra analysis and earthquake map such as explained [1], [2], and [14].

\section{CONCLUSIONS}

There was an extreme difference in structures destruction from entirely failure to small to non-structural destruction in Pidie Jaya earthquake. This destruction disparity could be added from the seismic response and building vulnerability connected with a difference in a local soil profile. There were also some liquefactions disasters of the abutment, retaining walls failures and liquefaction phenomena were recognized.

Liquefaction existences were documented in Manohara site as sand boils suggestion liquefaction at west coast along shorelines were also recognized. Most single and multistorey structures or public community area within 500-6000 $\mathrm{m}$ distance from epicenter was destroyed and completely collapse due to foundations failures. For Meureudu city development, strengthen approval for new construction in this area and seismic resistance buildings with the improvement of soil must be implemented, foundation type for solving liquefaction failure must be planned.

Initial seismic hazard probabilistic analysis has been directed for the research, yet more advanced research needs to be steered onto Sumatra Fault Line which has a potential to cause significant earthquakes in the future. Simple process expected for potential liquefaction analysis for peak surface acceleration ranging from $0.25 \mathrm{~g}$ to $0.325 \mathrm{~g}$ needs to compact for saturated sandy or silty sand layer to attain exceeding $(70-80 \%)$ relative density (Dr).

The magnitude of Pidie Jaya earthquake which is 6.4SR is smaller than the most significant earthquake in Aceh history within last ten years. The most significant earthquake in Aceh noted as 9.3SR on 26th December 2004. At that time, no significant destruction happen around Pidie Jaya. However, the distance of the earthquake source is more dominant than the magnitude regarding destruction level. The energy released from earthquake source may be closer to the affected area than to hypocentre. As a result, the Pidie Jaya earthquake effect is higher than the previous magnitude of 9.3SR. Geotechnical mitigation procedures such as parameter record equipment system to understand features of seismic ground motions at the local site in sources potential in the future and development of design response spectra have to be applied to propose a building improvement code. The guideline for appropriate in the reconstruction of the affected area. Microzonation and hazard maps need to be established for a further formulation of risk mitigation strategies which is relevant as suggested by [1].

\section{ACKNOWLEDGMENTS}

The authors would like to thanks their respective universities, Geotechnics and Soil Mechanics Laboratory staff of Syiah Kuala University for their support in all possible ways. Moreover, also would like to extend special thanks to the sponsored by Syiah Kuala University Research Center for Professor Grant Scheme Year 2017 No: 1442/ UN11/SP/PNBP/2017 date 18 Mei 2017.

\section{REFERENCES}

[1] Hendriyawan, Irsyam, M., Asrurufak, M., Meilano, I., Natawidjaja, D.H., Widiyantoro, S., Nugraha, A.D., Sakti, L.M., Sabaruddin, A., Faisal, L., Simatupang, P.T., Hutapea, B.M., and Afriansyah, T., Recent Efforts to Mitigate the Impacts of Earthquake Hazard in Indonesia from Geotechnical Engineering Perspective, Developments in Earthquake Geotechnics, pp 131-150, (2017).

[2] Irsyam, M., Dangkua, D.T., Hendriyawan, Hoedajanto, D., Hutapea, B.M., Kertapati, E.K., Boen, T., and Petersen, M.D., Proposed Seismic Hazard Maps of Sumatra and Java Islands and Microzonation Study of Jakarta City, Indonesia, Journal of Earth System Science, Vol. 117, Supplement 2, pp 865-878, (2008).

[3] Munirwansyah, Munirwan, R.P., Lime-Clay Stabilization to Modified the Characteristic of Mechanical Properties and Reduce the Swelling Subgrade, International Conference on Engineering and Science for Research Development, Banda Aceh, Indonesia, (2016).

[4] Munirwansyah, Munirwan, R.P., Stabilization on Expansive Soil for Sub-Grade for Geotechnical Disaster Approach, International Journal of Disaster Management, Vol. 1, No. 1, pp 8-19, (2017)

[5] Koseki, J., Shibuya, S., Mitigation of Disasters by Earthquakes, Tsunamis, and Rains using Geosynthetic-Reinforced Soil Retaining Walls and Embankments, Transp. Infrastructure. Geotech. 1, pp 231261, (2014).

[6] Sharma, K., Deng, L., Geotechnical Engineering Aspect of The 2015 Gorkha, Nepal, Earthquake, The 1st International Symposium on Soil Dynamics and Geotechnical Sustainability, Hongkong, (2016).

[7] Risk Engineering Inc., EZF-RISK, Software for In-depth Seismic Hazard Analysis, Boulder, Colorado, USA. (2004).

[8] Sengara, I.W. et al., Report on Preliminary Study and Reconnaissance Survey of Aceh Earthquake and Tsunami disaster, December 2004 Aceh's Earthquake and Tsunami Disaster Task Force, Institute of Technology Bandung, Indonesia, (2005).

[9] Avouac, J.P., Ayoub, F., Wei, S., Ampuero, J.P., Meng, L., Leprince, S. Jolivet, R., Duputel, Z., and Helmberger, D., The 2013, Mw 7.7 Balochistan Earthquake, Energetic Strike-Slip Reactivation of a Thrust Fault, Earth and Planetary Science Letters, Vol. 391, pp 128134, (2014).

[10] Amoly, R.S., Bilsel, H., and Ishihara, K., Cyclic Resistance versus Shear Wave Velocity as Affected by Aging of Sandy Deposits, 6th International Conference on Earthquake Geotechnical Engineering, Christchurch, New Zealand, (2015).

[11] Amoly, R.S., Ishihara, K., and Bisel, H., Relations Between Liquefaction Resistance and Shear Wave Velocity as Affected by Aging of Sand Deposits, Journal of Seismology and Earthquake Engineering, Vol. 17, Issue 1, pp 19-30, (2015).

[12] Chiou, B.S.J., and Youngs, R.R., Update of the Chiou and Youngs NGA Model for the Average Horizontal Component of Peak Ground Motion and Response Spectra, Earthquake Spectra, Vol. 30, Issue 3 (2014). 